\title{
Changing pattern of settlement structure in rural West Bengal
}

\author{
Falguni Dey ${ }^{1}$, Sukla Bhaduri ${ }^{2}$ \\ ${ }^{I}$ (Senior Research Fellow, Department of Geography, University of Calcutta, India) \\ ${ }_{2}^{2}$ (Professor, Department of Geography, University of Calcutta, India)
}

\begin{abstract}
Temporal effect over spatial dimension has been a long standing issue for the geographers to study settlement pattern both in rural and urban areas across the world. Rural areas are always the area of the masses whereas urban areas are the area of a relatively smaller number of population. Over the period of time, a little or no change has taken place in the rural areas which are nevertheless the pivotal areas for policy making and its execution. On the other hand urban areas are growing both horizontally and vertically in every aspects of human welfare. Census of India has categorised population size into various classes to understand the population growth pattern in various decades. This has resulted in to VII classes of various population sizes along with number of villages and total population under individual classes. The authors in this endeavour have attempted to analyse the changing pattern of rural settlements in West Bengal.
\end{abstract}

Keywords: population growth, regional disparity, rural service centre, rural structural change, village size

\section{INTRODUCTION}

Ever since man learned agriculture, he started settling in and around the agricultural land. Agriculture as a sole and predominant factor influenced various nomadic groups to club and settle permanently across the world. Since water is a basic need of agriculture, areas around source of water such as river, lake, pond etc. came up as an alternate geographical area of settlement. This historical event fulfilled the demand and supply of food in one hand and formation of clustered human settlement on the other. With increasing success and meeting the needs through agriculture, small patches of human habitat started growing in terms of population size and number of settlements. Nevertheless man started living comfortably in his esteemed house with the family members but at the same time, he started moving towards the upper order of settlement to avail better standard of living. The transfer of population and material is not necessarily unidirectional. In fact, quite often, the movement of population takes place from smaller centers to larger ones [1]. This trend of transfer of population helps rural growth-points change from a simpler structure to a complex one and acts as a rural service centre with a silent indication of future urban prospect. Hamlets, Villages, Towns and Cities are mutually dependent on each other and they coexist as a unified system of settlements in any region, state or nation. The notion of interdependence between settlements of different sizes and categories is of fundamental importance in settlement geographical studies [2].Temporal effect over spatial dimension has been a long standing issue for the geographers to study settlement pattern both in rural and urban areas across the world. Rural areas have always been the area of the masses whereas urban areas are the area of relatively smaller number of populations but with better quality of life. Over the period of time, a little or no change has taken place in the rural areas which are nevertheless the pivotal areas for policy making and its execution. Census of India has categorised rural population size into various classes (Table -1$)$ both at state and national level to understand the population growth pattern in various decades.

Table - 1: Size-class of Rural Settlement in West Bengal and India, 2011

\begin{tabular}{|c|c|c|c|c|c|c|c|c|}
\hline & \multicolumn{4}{|c|}{ TOTAL } & \multicolumn{3}{c|}{ IN PERCENTAGE } \\
\hline & \multicolumn{2}{|c|}{ NO. OF VILLAGES } & \multicolumn{2}{|c|}{ RURAL POPULATION } & \multicolumn{2}{c|}{$\begin{array}{c}\text { NO. OF } \\
\text { VLLLAG }\end{array}$} & \multicolumn{2}{|c|}{$\begin{array}{c}\text { RURAL } \\
\text { POPULATION }\end{array}$} \\
\hline $\begin{array}{c}\text { SETTLEMENT } \\
\text { CLASS }\end{array}$ & $\begin{array}{c}\text { West } \\
\text { Bengal }\end{array}$ & India & $\begin{array}{c}\text { West } \\
\text { Bengal }\end{array}$ & India & $\begin{array}{c}\text { West } \\
\text { Bengal }\end{array}$ & India & $\begin{array}{c}\text { West } \\
\text { Bengal }\end{array}$ & India \\
\hline$<\mathbf{2 0 0}$ & 3640 & 82149 & 3,91136 & 81,79066 & 9.71 & 13.74 & 0.62 & 0.98 \\
\hline $\mathbf{2 0 0}-\mathbf{4 9 9}$ & 6848 & 1,14726 & 23,85653 & $3,96,83027$ & 18.27 & 19.2 & 3.78 & 4.76 \\
\hline $\mathbf{5 0 0 - 9 9 9}$ & 8574 & 1,41761 & 62,52663 & $10,32,91220$ & 22.9 & 23.7 & 10.04 & 12.4 \\
\hline $\mathbf{1 0 0 0}-\mathbf{1 9 9 9}$ & 8731 & 1,39136 & $1,24,35699$ & $19,74,96806$ & 23.3 & 23.28 & 20.01 & 23.7 \\
\hline $\mathbf{2 0 0 0}-\mathbf{4 9 9 9}$ & 7552 & 96388 & $2,31,54974$ & $28,86,37987$ & 20.15 & 16.13 & 37.2 & 34.56 \\
\hline $\mathbf{5 0 0 0} \mathbf{- 9 9 9 9}$ & 1716 & 18641 & $1,14,00608$ & $12,38,08537$ & 4.57 & 3.17 & 18.34 & 14.9 \\
\hline$>\mathbf{1 0 0 0 0}$ & 417 & 4682 & 61,62380 & $7,23,66805$ & 1.1 & 0.78 & 10.01 & 8.7 \\
\hline TOTAL & 37,478 & 5,97483 & $6,21,83113$ & $83,34,63448$ & 100 & 100 & 100 & 100 \\
\hline
\end{tabular}




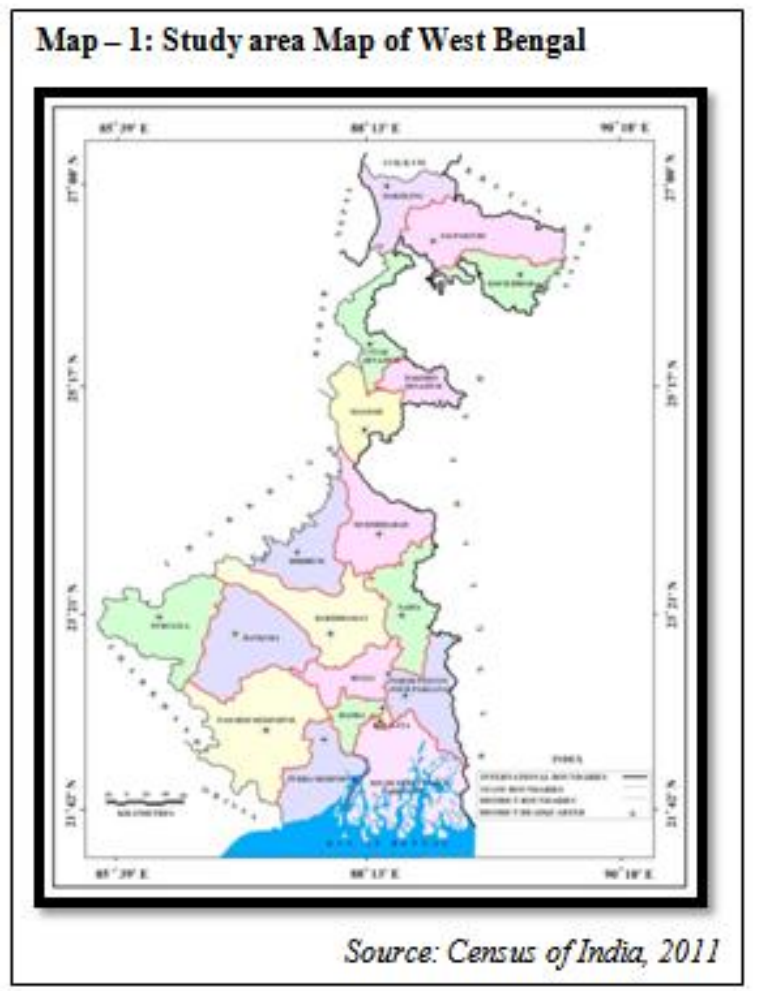

\section{STUDY AREA}

West Bengal $\left(88,752 \mathrm{~km}^{2}\right)$ is the only Indian state that extends from the Himalaya in the north to the Bay of Bengal in the south (Map - 1). It can be divided into nine physiographic provinces of which the Himalayas; the western plateaus; the northern and western alluvial fans and the Ganga delta are the most important. The entire region is bifurcated by many rivers like Teesta, Hugli, Damodar, Ajay, Rupnarayan and their numerous tributaries. According to Census of India 2011, West Bengal has a total 9,13,47736 population of which 6,21,83113 (68.07\%) are rural population. On the other hand West Bengal has a total 37,478 number inhabited villages of various population size class (Table -1 ). During various historical eras diverse racial groups invaded and lived in different parts of West Bengal due to vast reserve of natural resources which serves the basis of agrarian economy. Cultural assimilation and diffusion was the obvious outcome when stronger invaders replaced the former group. The population of West Bengal has not descended from one parent race, but it is the result of a mixture of diverse racial groups coming to this country during different periods of prehistoric and later ages. For better administration the districts of West Bengal are divided into the following main types $($ Table -2$)$.

Table - 2: Administrative Divisions of West Bengal, 2011

\begin{tabular}{|c|l|l|l|l|}
\hline $\begin{array}{c}\text { Sl. } \\
\text { No. }\end{array}$ & \multicolumn{1}{|c|}{$\begin{array}{c}\text { Administrative } \\
\text { Divisions }\end{array}$} & $\begin{array}{c}\text { No. of Inhabited } \\
\text { Villages }\end{array}$ & $\begin{array}{c}\text { Rural } \\
\text { Population }\end{array}$ & \multicolumn{1}{c|}{ Districts } \\
\hline 1. & JalpaiguriDivision & 7,137 & $1,39,93079$ & $\begin{array}{l}\text { Darjiling, Jalpaiguri, Koch Bihar, Uttar Dinajpur, Dakshin } \\
\text { Dinajpur, Maldah }\end{array}$ \\
\hline 2. & $\begin{array}{l}\text { Barddhaman } \\
\text { Division }\end{array}$ & 23,080 & $2,66,30500$ & $\begin{array}{l}\text { Birbhum, Barddhaman, Bankura, Puruliya, Hugli, Paschim } \\
\text { Medinipur, Purba Medinipur }\end{array}$ \\
\hline 3. & $\begin{array}{l}\text { Presidency } \\
\text { Division }\end{array}$ & 7,261 & $2,15,59534$ & $\begin{array}{l}\text { Murshidabad, Nadia, Haora, Kolkata (Total urban), North } \\
\text { 24 Parganas and South 24 Parganas }\end{array}$ \\
\hline
\end{tabular}

\section{Objectives}

To answer the research questions raised in this paper, the following objectives are taken into consideration:-

a. To analyze the size-class variation of rural settlement in West Bengal

b. To explain the changing structure of rural population in West Bengal

c. To compare the change in rural intensity in the districts of West Bengal

d. To examine the regional disparity of rural settlement in the districts of West Bengal 


\section{Database and Methodology}

The entire work is based on census of India data during the time period 1961 to 2011. Settlement size class and its category have been considered as per census of India guidelines. Various mathematical techniques and statistical methods are applied to justify the research objectives raised in this paper. Rural Intensity Index method has been applied in considering the number of inhabited villages and rural population of all the districts. The newest district Alipurduar, the broken piece of Jalpaiguri has not been taken into consideration due to unavailability of data. Whereas, Kolkata being a hundred percent urban district, has not been considered. Regression Analysis has been done to understand the interrelationship between different demographic factors. Sopher's Disparity Index has also been calculated to find out regional disparity in terms of village size class in different districts of West Bengal. On the other hand Map Info software techniques have also been applied to generate rural intensity mapping in order to support research objectives.

\section{RESULT AND DISCUSSION}

\section{Rural Settlement Size Class Variation}

Population growth in West Bengal is a rapid process. But rural population has decreased from 76.1 percent in 1951 to just 68.1 percent in 2011. Therefore no significant change in rural population has been noticed in last 60 years. Population size and its concentration is one of the most common approaches while studying rural geography. Settlements with different sizes and categories are interdependent from top to the bottom order of settlement size and vice versa. In case of West Bengal the history of last 50 years of the rural demographic change is incredibly dynamic in nature (Fig- 1).
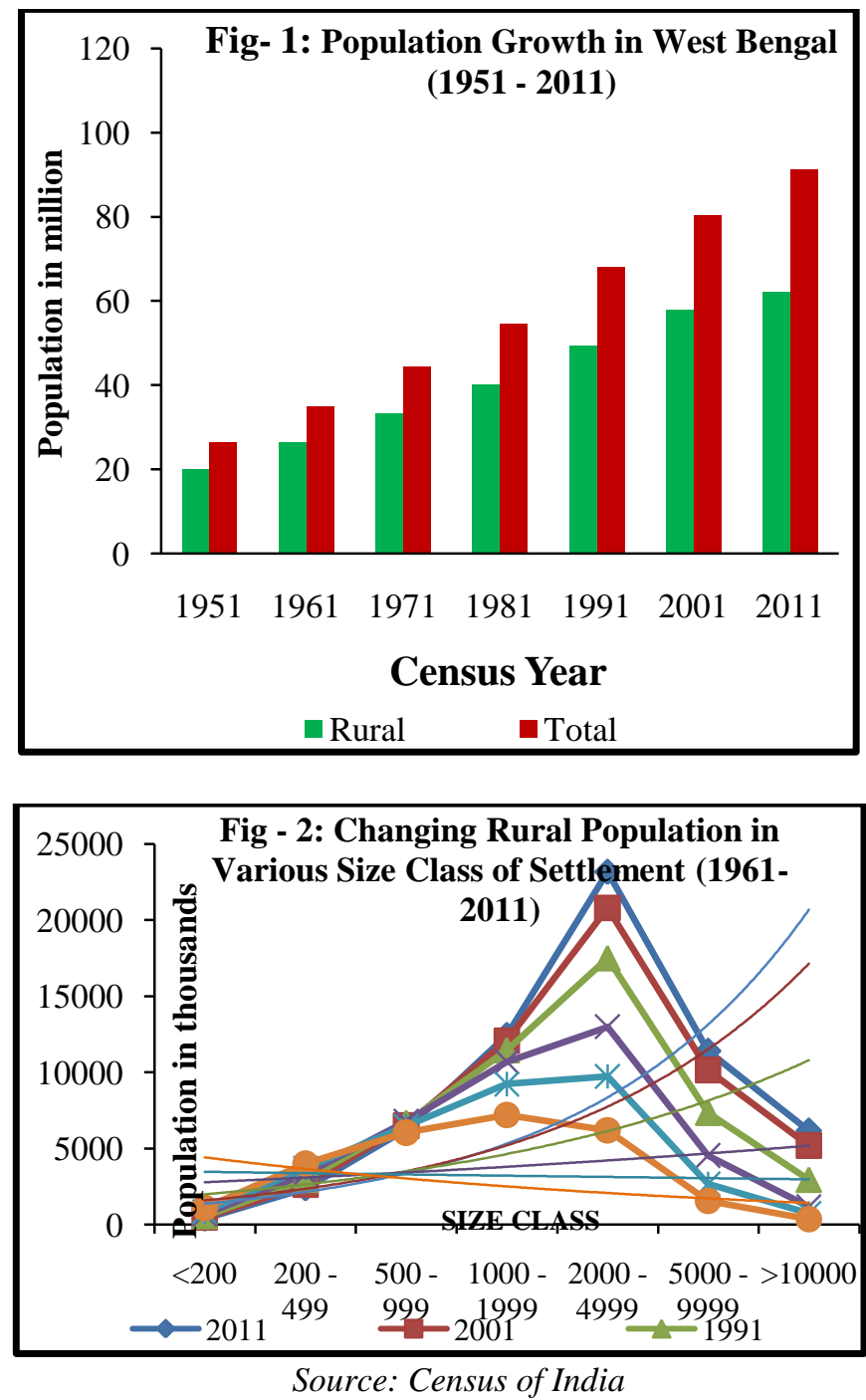
With increasing decades, rural population of West Bengal has moved towards the medium and large size categories of rural settlements. This process has helped hamlets and small villages to be reduced both in number and size. On the other hand due to increasing density in urban areas, a counter trend of urbanization is taking place and people are moving down towards sub urban areas in the settlement order. This entire process of rural demographic change has witnessed two distinct phase, i.e. early advent until 1981 and rapid growth during post 1991. Demographic change in rural settlement size and number has its direct impact on social, economic, cultural and political environment of the area.

As compared to rural population, number of inhabited villages has also reduced in a very negligible rate in West Bengal. In 1901 West Bengal had 44276 inhabited villages which reduced to 38474 in 1951 and to just 37478 in 2011, i.e. in last 110 years only 6798 number of villages have been reduced (Fig - 3). Decrease in number of villages indicates that the existing villages have merged into urban areas due to creation of or addition to statutory/census towns/OGs after 1991. Similarly declassification of urban units in 1991 to merge into the rural frame has resulted in increase in the number of villages (mouzas).
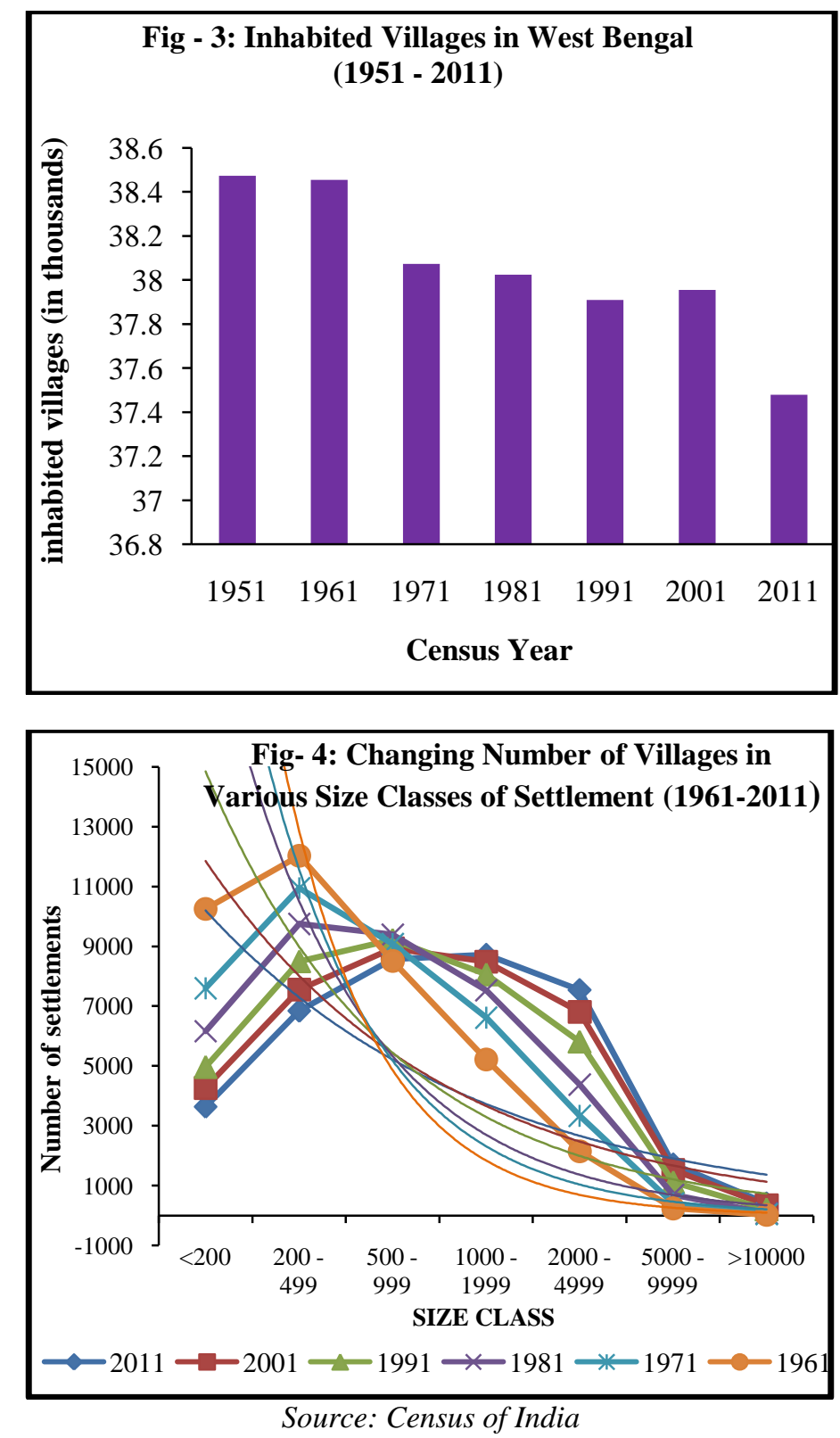

Villages are growing in size, particularly medium and large categories. This reflects a change in rural structure, mainly due to industrial growth and development of transport facilities in recent times [3]. Researches in settlement geography study shows that small size villages are almost on way to extinction. Maximum numbers of villages are mainly under medium to large size category. Inabilities to afford urban cost of living, but at the same time aspirations to meet urban quality of life, rural people are moving up in the settlement order. This

DOI: 10.9790/0837-2109112232 www.iosrjournals.org $\quad 25 \mid$ Page


process is leading to increased number of large size villages which has already turned out be a stable rural growth centre. Large size villages on the other hand fail to satisfy all the census criteria to be called an urban area, therefore could not be promoted to census towns. These villages lack 75 percent and above male workers' engagement in non-agricultural sector of economy.

As per 2011 census West Bengal ranks $2^{\text {nd }}$ highest in population density (just after Bihar) among all Indian states. A comparative analysis at national and state level shows that average population per village has an increasing trend towards the upper order of settlement. At the same time in all the classes of settlement average number of villagers in case of West Bengal has always been higher than the national average (Table -3 ). Therefore the axis of rural population both India and West Bengal lies in $2000-4999$ class of settlement size (Fig- 4). On the other hand maximum number of villages of both India and West Bengal are of 1000-1999 class of population size. Rapid urbanization in West Bengal during 2001 - 2011 census year although shows a promising trend of urban development.

\begin{tabular}{|l|l|l|}
\hline \multicolumn{3}{|l|}{ Table - 3: Average Population per Inhabited Village } \\
\hline Settlement Class & West Bengal & India \\
\hline$<\mathbf{2 0 0}$ & 107.45 & 99.56 \\
\hline $\mathbf{2 0 0}-\mathbf{4 9 9}$ & 348.37 & 345.89 \\
\hline $\mathbf{5 0 0}-\mathbf{9 9 9}$ & 729.25 & 728.62 \\
\hline $\mathbf{1 0 0 0}-\mathbf{1 9 9 9}$ & 1424.31 & 1419.45 \\
\hline $\mathbf{2 0 0 0}-\mathbf{4 9 9 9}$ & 3066.07 & 2994.54 \\
\hline $\mathbf{5 0 0 0}-\mathbf{9 9 9 9}$ & 6643.71 & 6641.73 \\
\hline$>\mathbf{1 0 0 0 0}$ & 14777.89 & 15456.38 \\
\hline TOTAL & 1659.19 & 1394.95 \\
\hline
\end{tabular}

Source: Census of India, 2011

\section{Factors Influencing Rural Structural Change}

a. Counter Urbanization: - The process of urbanization is gradually rising at its apex. In West Bengal, Kolkata being the both capital and primate city attracts masses not only from the rest of Bengal but from the entire eastern India. This process eventually created population explosion and recorded West Bengal as $2^{\text {nd }}$ most densely populated state in India (Census of India 2011). Cosy and compact settlement, pollution, traffic congestion, lack of breathing space and many other factors all together forced people live away from the city core and reside in comparatively hospitable country sides. Out growth is therefore evident as a result of counter urbanization process and catalyst of rural structural change in West Bengal.

b. Transport Development: - Transport network development by virtue of its connectivity and accessibility services helps to reduce regional imbalance. Change in rural structure mainly due to industrial growth and development of transport facilities in recent times [4] has influenced people settle away from city but commute longer distance within a very short period of time. National highway, State highway, Expresses way, galloping and super fast transport facilities both in road and railways have cut down travel time. The villages alongside the road and railways are rapidly transforming into a potential rural service centre.

Figure - 5: Factors Influencing Structural Change in Rural West Bengal

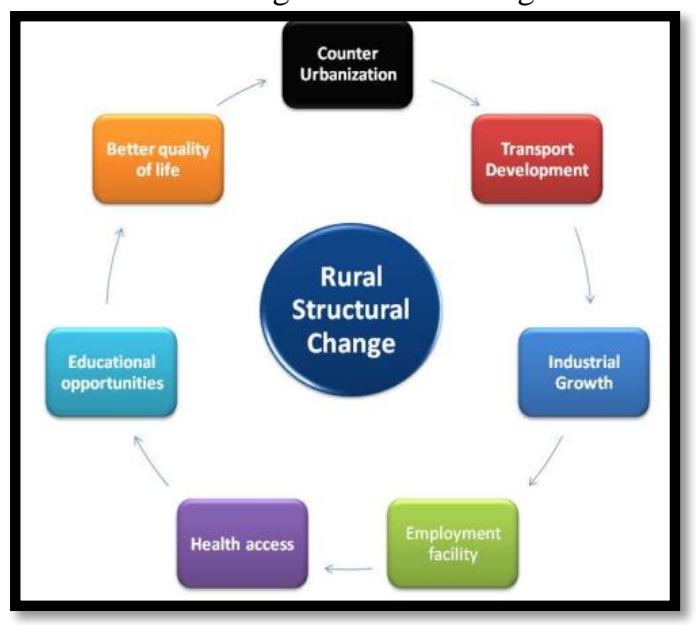

Source: Composed by the author 
c. Industrial Growth: - One of the most discussed issues of recent times in the history of West Bengal is it's strategically shift to industrial economy. West Bengal predominantly being an agricultural state is highly potential and a productive agricultural region. On the other hand the state is also blessed with mineral resources which help in building market for industrial raw material. In spite of this controversy of industry over agriculture, the role of industry in economic development is unputdownable. Labor forces from across West Bengal villages are working in large number in industrial sectors. When rest of the world is gradually shifting from abyss to zenith in the scale of economic activity how long West Bengal can remain exceptionally stagnant.

d. Employment Facility: - During post independence years economic planning in West Bengal has repeatedly failed to create job opportunity for educated and unemployed youths. Educated and uneducated, skilled and unskilled youths are coming out of their villages and migrating elsewhere in the world for economic reason. This has resulted out sourcing in the village economy of Bengal. Potential people are leaving their home behind in search of destiny, whereas the remaining helpless people are trying to put their intangible faith on unforeseen good days to come and pull them out of their misery. The transfer of population and material is not necessarily unidirectional. In fact, quite often, the movement of population takes place from smaller centers to larger ones [5].

e. Health Access: - Life expectancy, infant mortality rate, maternal mortality rate, number of hospitals, doctors, beds and many other health indicators depict very sharp rural urban contrast across West Bengal. Rural areas are the areas of deprivation and at the same time is the area of masses. Unfortunately these areas are highly neglected in terms of health access. Doctors deny working in village hospitals and as result people in the rural area are forced to visit subdivision or higher level of private nursing homes.

f. Educational Opportunities: - Education system in West Bengal from school to university level is suffering a setback. Insufficient number of school colleges, parental willingness to send their children to schools, household economic instability, together as a whole hindering the growth of education in rural Bengal. Moreover, rural areas in West Bengal are no more unaffected from globalization. Growing essence of English as a medium of learning is overcasting and replacing the age old vernacular education system. Owing to the fact, parents are no more interested to send their children to village primary schools; rather they are keener to admit them in private English medium schools.

g. Better Quality of Life: - Success is mostly attained in an urban area as compared with rural. Value of human life in an urban area is more justified. Entertainment facilities, scope to excel personal talents, access to modern technology and science etc. has immensely modified the life of an urban residual over the rural life.

\section{Rural Intensity Index}

In a broader sense population living in villages and number of inhabited villages are the two basic units of rural geographical study so far. Rural intensity index signifies the assessment of density distribution over a spatial dimension and its change detection in different time period. This spatial distribution over the period of time is essentially important from the perspective of rural development policy making. In case of West Bengal a unidirectional flow of decreasing intensity of rural area towards Kolkata is strongly evident. Apart from Kolkata other urban centres like Asansol and Siliguri does not really have much impact on it. Much change around these two urban centres has not been observed. Contrary to it, Kolkata being the capital city of West Bengal, rapid change in land use pattern, land value has been found in its neighbouring areas. This process has invariably a strong impact on socio-economic and politico-administrative characteristics of Kolkata city region as a part and the state of West Bengal as a whole.

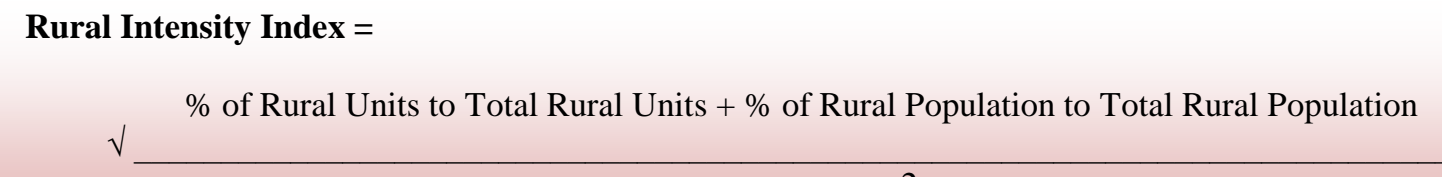

The entire demographic history of West Bengal since independence can broadly be categorised into following three heads:-

3.1 Post Independence Era (1951 - 1971): India flagged off with a new set of development goals from a point where British rulers left behind. During post independence era West Bengal was predominantly rural in 
nature. Excluding Kolkata, around 90 percent people used to live in rural agrarian social system. Whereas population composition of the then West Bengal was less of a native rather more of migratory in nature due to sharing international boundary with Bangladesh. Excluding Kolkata which is completely urban in nature there was a total of 14 districts (Purulia was a part of Manbhum district therefore was not included in West Bengal until 1961 census). Only Darjiling being the summer capital of British Empire had traces of urban development, other than that out of 14 districts, all other districts noted significantly high degree of rural intensity (Map - 2). Situation did not change much in 1961 once the inclusion of intensively rural Puruliya district took place (Table -4). Puruliya being the part of extended Chhotanagpur plateau region poses adverse climatic and physiographic conditions which in turn hinders the development of human habitat. In 1971 Haora district recorded a decreasing trend of rural intensity and rapid industrial urban development due to its adjacent location to Kolkata and eventual contagious spread effect (Map -3).
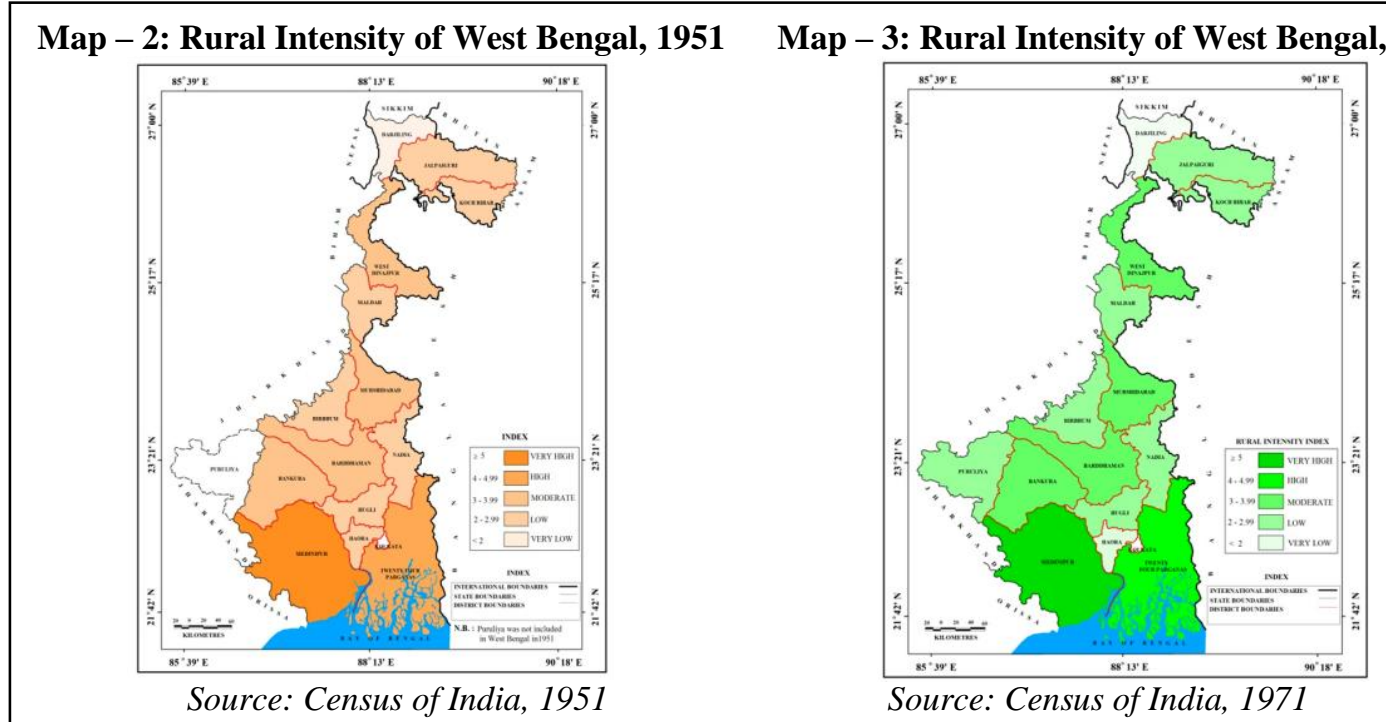

Map - 4: Rural Intensity of West Bengal, 1991
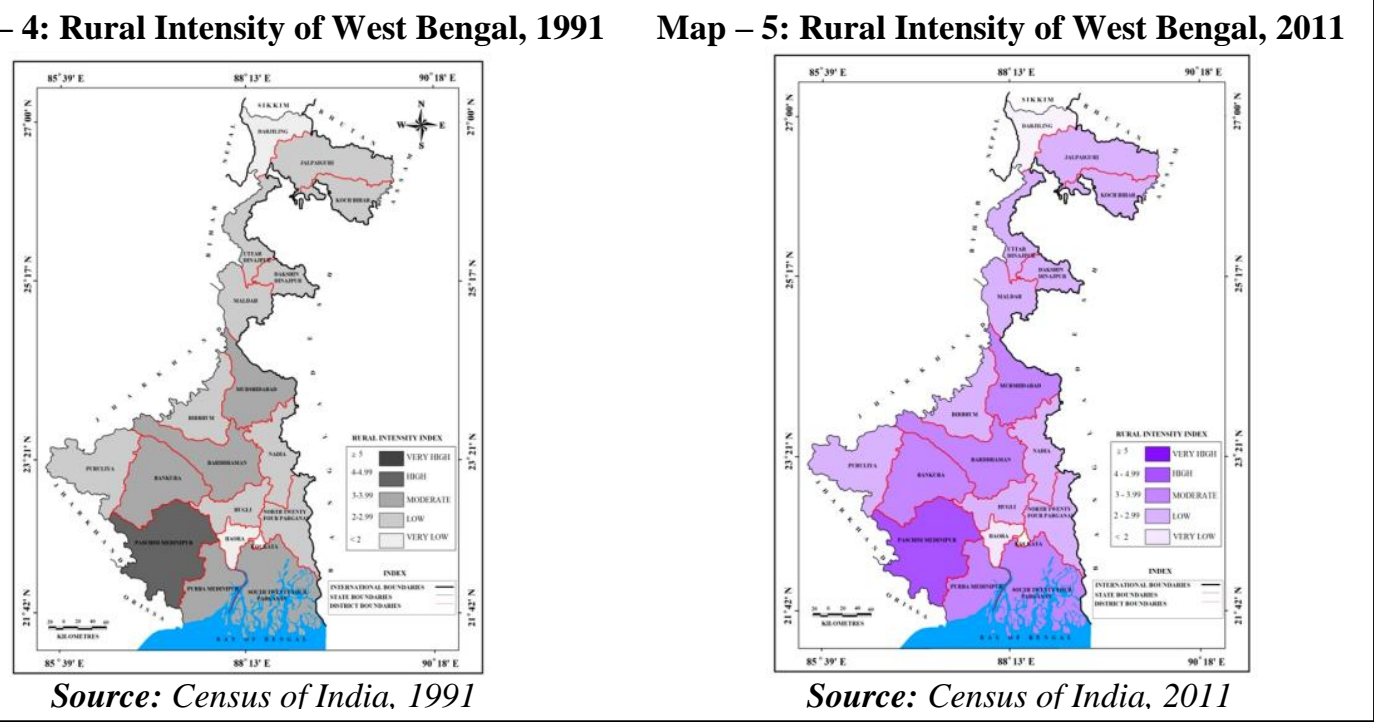

3.2 Late Independence Era (1971 - 1991): By this time it has already been two decades and more India got independence but rural intensity of West Bengal remained almost the same as it was before. Two successive census years i.e. 1971 and 1981 did not differ much from each other from the point of view of degree of rural intensity of the districts. Undivided Medinipur and 24 Parganas remained largely and highly rural in nature. Total number of villages of West Bengal in 1961 was 38,454 which reduced down to 38,024 only in 1981. On the other hand rural population almost doubled during this span of 20 years (Table - 4). In 1991 situation changed to a different level when West Dinajpur, Medinipur and 24 Parganas districts were divided and three new districts came into being. Rural intensity index values of the districts away from Kolkata started decreasing very slowly but adjacent districts like North 24 Parganas and Haora started leaving behind their rural nature at a very faster pace (Map - 4).

3.3 New Economic Era (1991 - 2011): Indian economy by this period of time had started strengthening itself riding on the pace of new economic policy. Impact of the new economic era helped in developing all the 
spheres of socio-economic environment only except rural areas. Position of the districts as per the degree of rural intensity remained same in almost three successive decades. On the other hand in a positive sense, almost zero to one district remained highly rural that is West Medinipur (Map - 5). Moreover during these decades more number of districts gradually approached towards low and very low degree of rural intensity (Table -4$)$. This trend indicates West Bengal is heading towards the process of urbanization.

Table - 4: Rural Intensity Index and Distribution of Districts in various Census Years

\begin{tabular}{|c|l|l|l|l|l|l|l|l|}
\hline NATURE AND DEGREE & $\mathbf{1 9 5 1}$ & $\mathbf{1 9 6 1}$ & $\mathbf{1 9 7 1}$ & $\mathbf{1 9 8 1}$ & $\mathbf{1 9 9 1}$ & $\mathbf{2 0 0 1}$ & $\mathbf{2 0 1 1}$ \\
\hline \multirow{4}{*}{ RURAL } & Very High & 1 & 1 & 1 & 1 & 0 & 0 & 0 \\
\cline { 2 - 10 } & High & 1 & 1 & 1 & 1 & 1 & 1 & 1 \\
\cline { 2 - 9 } & Moderate & 4 & 3 & 4 & 4 & 5 & 5 & 5 \\
\cline { 2 - 9 } & Low & 7 & 9 & 7 & 7 & 10 & 10 & 10 \\
\cline { 2 - 9 } & Very Low & 1 & 1 & 2 & 2 & 2 & 2 & 2 \\
\cline { 2 - 10 } & TOTAL & 14 & 15 & 15 & 15 & 18 & 18 & 18 \\
\hline
\end{tabular}

Figures signify number of districts (excluding Kolkata)

Source: Census of India, $1951-2011$

\section{Regional Disparities in Rural Settlement}

In India village is cocoon of the city and the city the cage of the village. One gets orphaned without the other, but one does not out himself asunder in either, from one's own typed environment. Moreover it is universalizing of the incipient perspectives of the microscopic rural atmosphere that stretches its expansive ken into a well-knit bondage with a macroscopic urban vista and finds fulfilment therein, beyond the pinches of hunger and cold. India stood apart as a model from other world models of a city and village life and had been able to infuse into the entire structure of the land [6]. During pre British time Indian villages were existed in a state of isolation from the rest of the world. Each was stable, self sufficient whole, controlling its own affairs and yielding to the outside world only a land tax through cautious intermediaries [7]. In case of regional isolation social factors like - caste, ethnicity and religion are no less important, rather plays a significant role in controlling the politicoadministrative environment of the state. West Bengal in this context is an eminent sufferer of prolonged social movements from various backward regions. Dividing the districts to serve the purpose of better administration cannot solely wither the regional problems.

Fig - 6: Regional Disparities in Settlement Size Classes in West Bengal in 2011

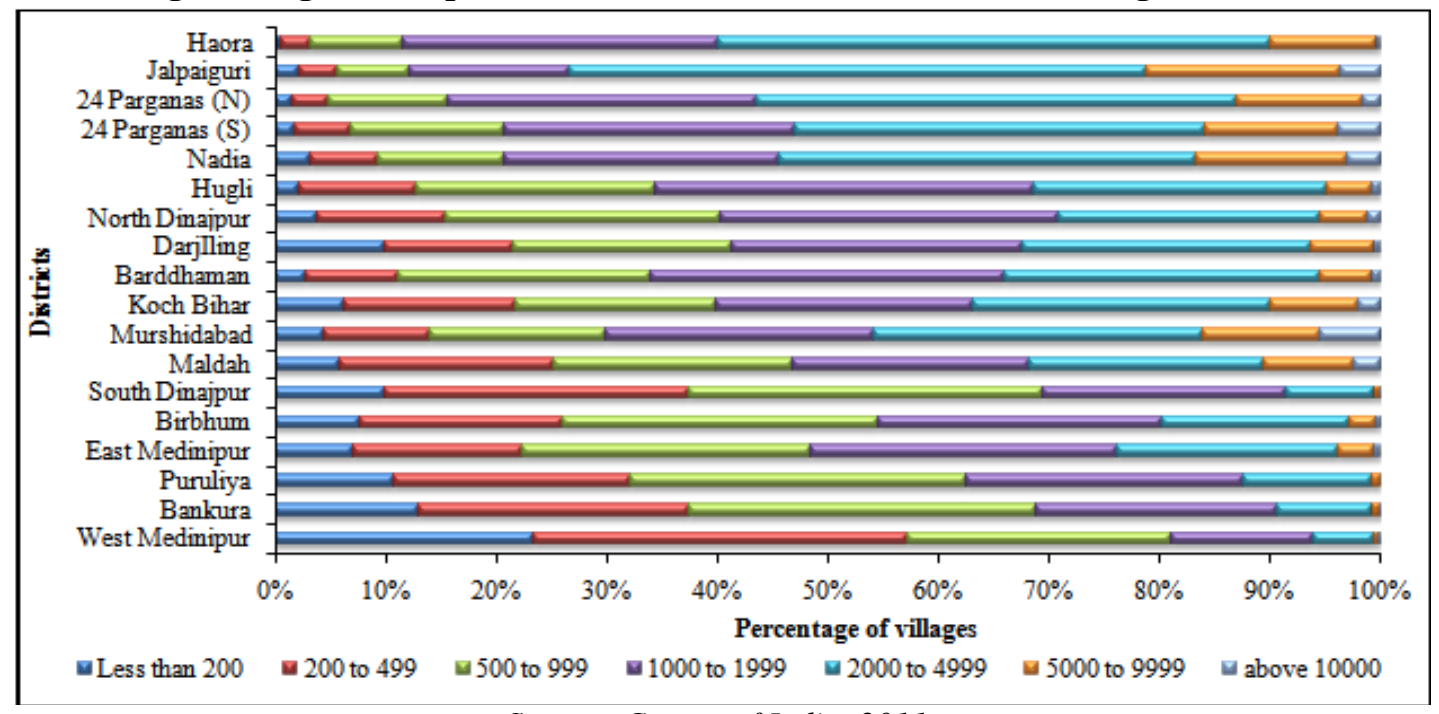

Source: Census of India, 2011

In India settlement structure is diversified in terms of dispersed to nucleated or in size from a hamlet to large villages. Physiographically West Bengal is a diversified region where hill area settlements are smaller in size whereas in plain areas settlements are larger in size. A distinct pattern of regional disparity in settlement size can be inferred from the districts of West Bengal (Fig - 6). Districts with high rural intensity index , like - Paschim Medinipur, Purba Medinipur, Bankura, Puruliya, Birbhum, South Dinajpur, North Dinajpur and Murshidabad records maximum number of smaller size settlements ( < 200; $200-500$ and 500 - 999) but minimum number of larger size settlements ( $2000-4999 ; 5000$ - 9999 and >10000). On the other hand a reverse type of distribution of settlements is observed in the districts with low rural intensity index, like - Haora, Jalpaiguri, North 24 Parganas, Nadia and Hugli. Moreover, there are districts like Darjiling, Barddhaman, Koch Bihar, and 
Maldah where a balanced number of both small and large size settlements are observed. The correlation coefficient of the small size and large size settlements in West Bengal denotes a inverse relationship (Fig - 7).

Fig - 7: Interrelationship between Small and Large size Villages in the Districts of West Bengal in 2011

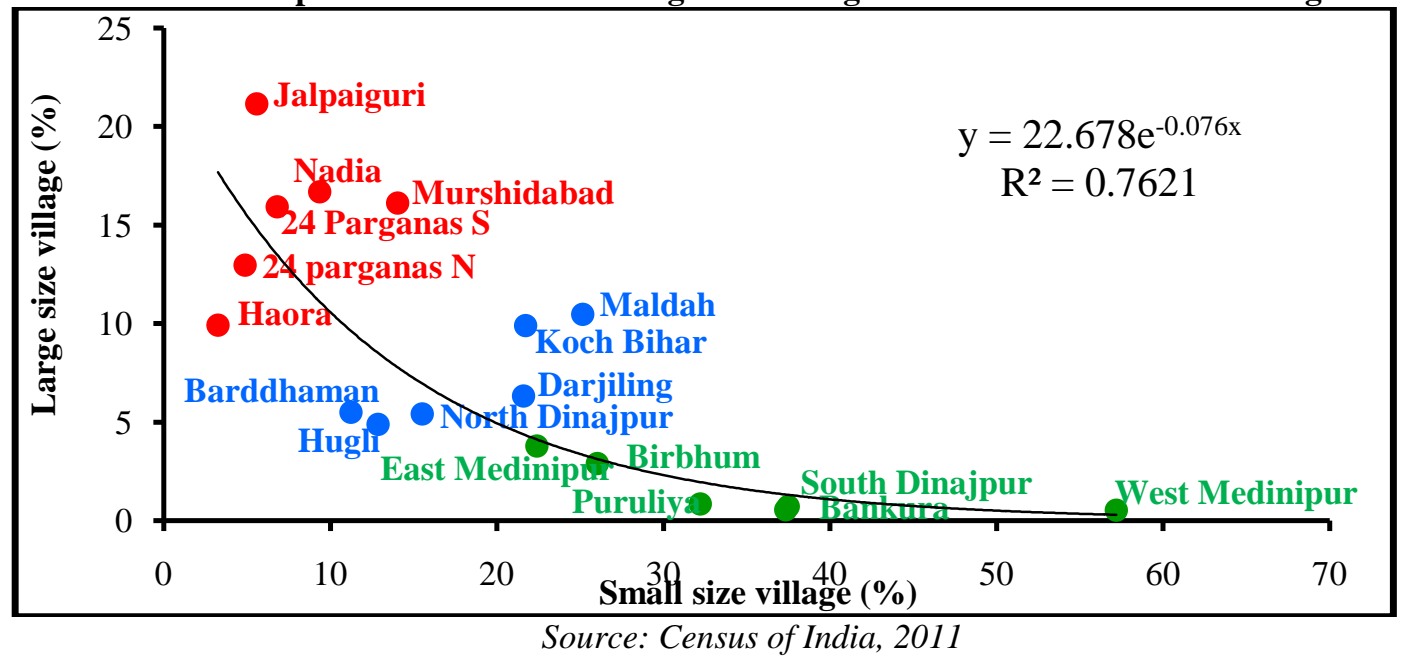

\section{Sopher's Disparity Index}

For the measurement of disparity in small and large size settlement, Sopher's Disparity Index (1974) modified by Kundu and Rao (1983) has been employed. Modified disparity index formula, as follows (where $\mathrm{X}^{1}$ represents Small Size Village and $\mathrm{X}^{2}$ Large Size Village):

$$
\text { Disparity Index }=\log \left(X^{2} / X^{1}\right)+\log \left(200-X^{1}\right) /\left(200-X^{2}\right)
$$

Table - 5: Degree of Inequality in Village Size in the Districts of West Bengal in 2011

\begin{tabular}{|c|c|c|c|c|c|}
\hline Districts & $\begin{array}{l}\text { \% of } \\
\text { Large } \\
\text { Size } \\
\text { Village } \\
\left(\mathbf{X}^{1}\right) \\
\end{array}$ & $\begin{array}{l}\% \text { of Small } \\
\text { Size Village } \\
\left(\mathrm{X}^{2}\right)\end{array}$ & $\operatorname{LOG}\left(\mathrm{X}^{2} / \mathrm{X}^{1}\right)$ & $\begin{array}{l}\text { LOG }\left(200-X^{1} /\right. \\
\left.200-X^{2}\right)\end{array}$ & $\begin{array}{l}\text { Disparity } \\
\text { Index }\end{array}$ \\
\hline Puruliya & 0.85 & 32.2 & -21.36345879 & 1.033436095 & -20.33002269 \\
\hline Bankura & 0.72 & 37.48 & -11.03124077 & 1.040054561 & -9.991186211 \\
\hline South Dinajpur & 0.56 & 37.35 & -6.243907259 & 1.040048857 & -5.203858402 \\
\hline West Medinipur & 0.52 & 57.18 & -6.187552253 & 1.067343173 & -5.12020908 \\
\hline Birbhum & 2.89 & 26.03 & 3.07112344 & 1.024206612 & 4.095330052 \\
\hline East Medinipur & 3.78 & 22.4 & 2.338125007 & 1.019249348 & 3.357374354 \\
\hline Hugli & 4.88 & 12.86 & 1.611285633 & 1.00798144 & 2.619267073 \\
\hline North Dinajpur & 5.42 & 15.52 & 1.622469856 & 1.010215987 & 2.632685844 \\
\hline Barddhaman & 5.5 & 11.24 & 1.419258866 & 1.005716235 & 2.424975101 \\
\hline Darjiling & 6.33 & 21.59 & 1.664894517 & 1.015831418 & 2.680725935 \\
\hline Koch Bihar & 9.89 & 21.73 & 1.343513574 & 1.01240592 & 2.355919494 \\
\hline Maldah & 10.47 & 25.15 & 1.373148239 & 1.015611924 & 2.388760163 \\
\hline Districts & $\begin{array}{l}\% \text { of } \\
\text { Small } \\
\text { Size } \\
\text { Village } \\
\left(\mathbf{X}^{1}\right) \\
\end{array}$ & $\begin{array}{l}\% \text { of Large } \\
\text { Size Village } \\
\left(\mathrm{X}^{2}\right)\end{array}$ & $\operatorname{LOG}\left(\mathrm{X}^{2} / \mathrm{X}^{1}\right)$ & $\begin{array}{l}\text { LOG }\left(200-X^{1} /\right. \\
\left.200-X^{2}\right)\end{array}$ & $\begin{array}{l}\text { Disparity } \\
\text { Index }\end{array}$ \\
\hline Haora & 3.26 & 9.93 & 1.942546881 & 1.006572909 & 2.949119791 \\
\hline 24 Parganas $(\mathrm{N})$ & 4.87 & 12.96 & 1.618266378 & 1.008094226 & 2.626360603 \\
\hline Jalpaiguri & 5.57 & 21.16 & 1.777175613 & 1.016115065 & 2.793290678 \\
\hline 24 Parganas $(\mathrm{S})$ & 6.81 & 15.93 & 1.442981388 & 1.009272312 & 2.4522537 \\
\hline Nadia & 9.37 & 16.69 & 1.258008162 & 1.007513783 & 2.265521945 \\
\hline Murshidabad & 14.05 & 16.11 & 1.051773497 & 1.00213643 & 2.053909927 \\
\hline
\end{tabular}

Source: Computed by the Author 
Different size class of settlement and their inequality in distribution is a major concern of rural urban studies. Factors like distance from city, physiographic set up, accessibility and connectivity, infrastructural development, growth of market etc. plays an important role for the structural evolution of rural settlements. So far the results of the Sopher's Disparity Index is concerned it is pertinent that western districts which are adjacent to Chhotanagpur plateau are the most deprived region of West Bengal. These districts suffer from adverse physical and climatic conditions and lack of infrastructural development. As a result it has recorded more number of small size isolated villages and less number of large size villages in these districts. South Dinajpur on the other hand appears to be almost a pocket like district of West Bengal within the territory of Bangladesh and remains deprived from the development processes. Haora, North and South 24 Parganas, Nadia districts enjoy high connectivity because of nearness to Kolkata. There is more number of large size settlements in these districts which would serve as potential urban centres in near future. Process of upward movement of rural population in the settlement order in these districts is also very fast due to increasing connectivity and growth of markets under KMA area. Maldah and Murshidabad districts are located on the either side of river Ganges and are benefited from fertile alluvial plain to set up a strong agrarian economy to feed both large and small size villages. Apart from these Darjiling, Jalpaiguri, Barddhaman, Hugli and Koch Bihar districts are in a balanced situation with almost equal proportion of both small and large size villages. Results of correlation coefficient and sopher's disparity index do not vary much (Table -5$)$.

\section{MAJOR FINDINGS}

The rate of decrease of rural population and number of rural settlements of West Bengal is extremely slow. Over the last half a century rural situation did not change much. More than half of the districts are under high rural intensity index. This situation does not satisfy the prospect of rapid urban development in West Bengal.

a. Small size villages are decreasing in number whereas there is a tendency of upward movement of people towards large size villages all over West Bengal. These large size villages are serving as rural service centres. Therefore the axis of rural population both in India and West Bengal stands on mid size villages. Counter urbanization on the other hand emphasises on the rurban development.

b. Factors like transport development, industrial growth, employment opportunities, health and education development are almost metamorphosing the internal and external genesis of rural West Bengal. New economic policies indebted towards rural development are indeed shaping up the rural structure.

c. Inequality in development of the districts is evident. Backward districts are blessed with more number of remote and isolated villages. Whereas advanced districts near to the capital city are rapidly transforming itself into future urban centres based on developed market economy and quality of life.

d. It is universalizing of the incipient perspectives of the microscopic rural atmosphere that stretches its expansive ken into a well-knit bondage with a macroscopic urban vista and finds fulfilment therein, beyond the pinches of hunger and cold. India stood apart as a model from other world models of a city and village life and had been able to infuse into the entire structure of the land

e. $\quad$ Except the total population, large size villages of West Bengal does not satisfy census of India with other prospective urban criteria like population density and engagement of 75 percent male workers in non agricultural sector of economy. These factors are obstructing large size villages of West Bengal to be awarded with urban dignity.

\section{CONCLUSION}

Pertaining to the issues discussed in this paper it could clearly be inferred that rural scenario of West Bengal is at a stake under rural development policy and planning. Deprivation and isolation of rural areas have almost entered into the genome of village life of West Bengal. Indeed in different decades since independence and new economic policy, a jerk of new initiatives took place but had it been more of a cooperative type with active participation of people. Movement of people towards the upper order of settlement may be an indication of dynamic nature of demography and settlement structure, but establishment of rural service centres in the lower order of settlement is much needed to improve the quality of life and increase purchasing power by creating job opportunity in rural areas. More emphasis on rural development issues in all the forthcoming five year plans is the need of the time.

\section{ACKNOWLEDGEMENT}

I would like to thank my supervisor, friends and family members for their invaluable guidance, technical suggestion and continuous support to motivate me and write this paper. 


\section{Book:}

\section{REFERENCES}

[1] S. Ghosh, Introduction to settlement geography (Orient Black Swan Private Limited, Kolkata, 2006).

[2] R. Ramachandran, Urbanization and urban systems in India (Oxford University Press, New Delhi, 1989).

[3] R. Y. Singh, Geography of settlements (Rawat Publications, New Delhi, 2002).

[4] Ibid

[5] S. Ghosh, Introduction to settlement geography (Orient Black Swan Private Limited, Kolkata, 2006).

[6] Ibid

\section{Chapters in books:}

[7] M. N. Srinivas, Village India - Studies in the Little Community, in M. Mckim (Ed.), Little communities in an indigenous civilization, (Larry W Price Books, Portland, OR, U.S.A. 1955) pp - 172. 